\title{
Performance Analysis of the Prosopis Juliflora wood Based 10 kWe Downdraft Gasifier
}

\author{
S.Sivakumar* ,S. Ragunathan ${ }^{\#}$ \\ *Department of Mechanical Engineering, Kumaraguru College of technology, Coimbatore, India-641047 \\ Email: Skshivas@yahoo.co.in \\ \#Department of Mechanical Engineering, AVS Engineering college,Salem, India
}

\begin{abstract}
Gasification of solid biomass into gas often referred as producer gas which has higher heating value can be used to operate internal combustion engine. Here an attempt has been made to successful gasification of Prosopis Juliflora Wood and identification of optimum equivalence ratios in downdraft double throat gasifier for generation of quality gas for onward generation of power. A small scale downdraft double throat wood gasifier is designed to deliver a power of $10 \mathrm{~kW} e$ to run an IC Engine also the the performance analysis like Specific gasification rate, Gas production rate,gas efficiency,fuel consumption rate are prdedicted for given conditions. The optimum equivalence ratio for wood have been estimated to 0.3 , the gas composition $\left(\mathrm{CO}, \mathrm{H}_{2}\right.$ ) and calorific value of wood is observed as $\mathrm{CO}=18.8 \%, \mathrm{H}_{2}=12.8 \%, \mathrm{CV}$ $=1082 \mathrm{Kcal} / \mathrm{nm}^{3}$.
\end{abstract}

\section{Indexing terms/Keywords}

Downdraft Gasifier, Equivalence Ratio, Specific gasification rate,

\section{Academic Discipline And Sub-Disciplines}

Mechanical Engineering,

\section{SUBJECT CLASSIFICATION}

\section{Thermal}

\section{TYPE (METHOD/APPROACH)}

\section{Experimental,Analysis}

\section{INTRODUCTION}

A great heap of exertion is on its way all over the globe to tap the non-conventional energy resources. Non-conventional energy resources like bio mass, wind and solar are used for power generation instead of nonrenewable energy resources such as diesel, petroleum ,etc. because nonrenewable energy resources are becoming scarce one. Bio mass provides better efficiency because it is cost-effective, ecofriendly and ensures less emission due to bio chemical conversion process.

Biomass replaces nonrenewable fuels in energy devices for satisfying $14 \%$ of the world's energy demands (Hall et al, 1992). Biomass is the most important source of energy in developing nations, providing $35 \%$ of their energy (Siva Kumar et al,2008). Biomass can be changed into liquid, solid and gaseous fuels through thermo chemical conversion process. (Tapas Patra and Sheth, 2015).Gasification is one of the foremost biomass conversion technologies with internal combustion engines being regularly used as foremost movers in biogas power plant units (Felipe et al, 2012). A number of researchers , namely Giltrap et al,(2003), Jayah et al, (2003); Gao and Li (2008); Sharma (2008) and Ratnadhariya and Channiwala (2009), agree that, in case of downdraft gasifiers, the modeling of chemical reactions that takes place in different zones should be carried out separately

The objective of the present work is to conduct a performance analysis of a down draft double throat gasifier with Prosopis Juliflora wood( seema karuvellam wood) as a feed stock to generate tar free producer gas, which will help to run the IC Engine. Also to predict the performance analysis like Specific gasification rate, Gas production rate,gas efficiency,fuel consumption rate are prdedicted for given conditions.

\section{MATERIAL AND METHODS}

\subsection{Biomass}

Biomass used in this study is Prosopis juliflora wood. The proximate and ultimate analysis is conducted and the values are listed in Table 1. Reed and Das (1988) have reported that low moisture content is preferred because of its higher gross energy content and to produce a high-quality producer gas, the moisture content of the Prosopis juliflora has been kept at $4.03 \%$ for this experimental analysis. 
Table 1. Prosopis juliflora wood properties

\begin{tabular}{|l|l|l|l|}
\hline \multicolumn{2}{|l|}{ Ultimate Analysis } & \multicolumn{2}{l|}{ Proximate Analysis } \\
\hline Properties & $\%$ & Properties & $\%$ \\
\hline C & 42.22 & moisture & 4.03 \\
\hline Hydrogen & 5.01 & Volatile Matter & 84.64 \\
\hline N & 0.21 & Fixed Carbon & 10.23 \\
\hline S & 0.002 & $\begin{array}{l}\text { Calorific Value } \\
\text { ( kcal/kg) }\end{array}$ & 4593.061 \\
O2 & 46.25 & & \\
ASH & 1.10 & & \\
& & &
\end{tabular}

\subsection{Experimental Approach and Measurement System.}

Experimental apparatus and Measurement System is illustrated in Figure.1. The steel apparatus consists of gasification reactor, cyclone, induced draft blower at 6 positions with fittings and valves. The top of the reactor was closed and bottom of the reactor was water sealed to arrest the escaping gas and to collect the tar..

The feedstock for this experiment is Prosopis juliflora cut into $2 \mathrm{~cm}$ cubes approximately which has a bulk density of around $400 \mathrm{~kg} / \mathrm{m}^{3}$. The Prosopis juliflora cubes are loaded into the reactor at the feedstock hopper. The gasification approaches namely: single stage air supply have been studied in the same reactor. For the single-stage, air was supplied only at the combustion nozzles and valves V1 and V2 as shown in Figure. 2. The air supply rate was controlled by observing the flow rate at rotameters 1 and 2 to accordingly adjust control valve 1 and control valve 2 . The measuring instruments are installed at appropriate position to collect the data's like Producer gas flow, level transmitter, flow counting, temperature of the reactor and analysing of gases.

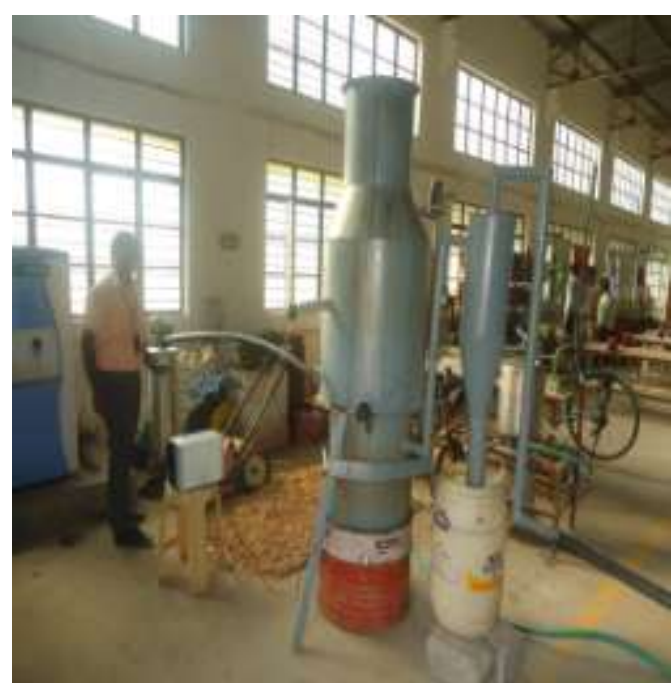

Fig.1 Experimental Setup of Downdraft gasifier gasifier

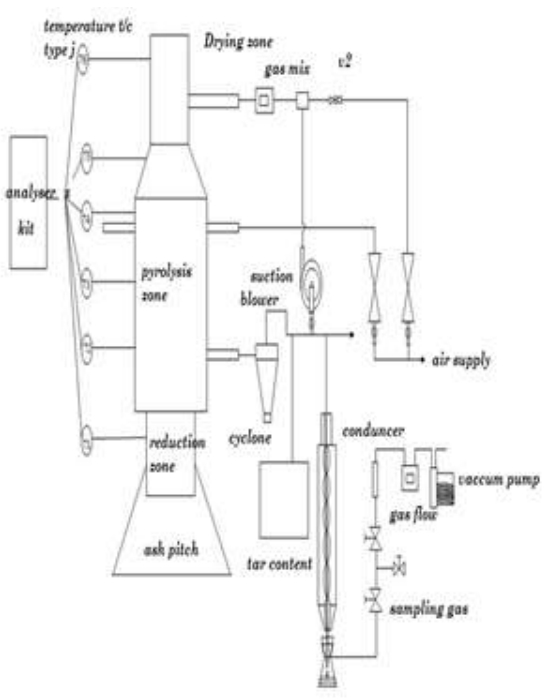

Fig.2: Experimental and measurement setup of Downdraft

\section{RESULTS AND DISCUSSIONS}

\subsection{Equivalence ratio Vs Specific Gasification Rate(SGR)}

The graph Figure 3.it shows that the relationship between the equivalence ratio and specific gasfication rate. The equivalence ratio is given as the values as $0.2-0.4$.and the specific gasification rate is given as the value as between $0-6$. There are four inputs and four outputs are obtained and the SGR values are lies between $2 \mathrm{Nm}^{3} / \mathrm{Kg} \mathrm{to} 3 \mathrm{Nm}^{3} / \mathrm{Kg}$ 


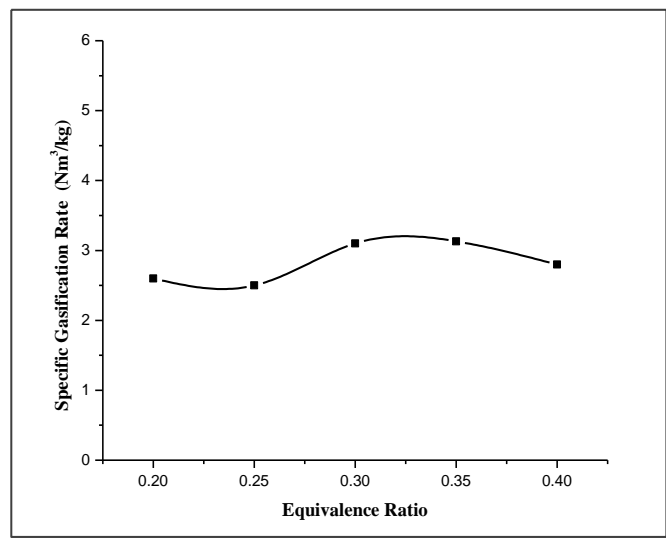

Figure 3 Equivalence ratio Vs SGR

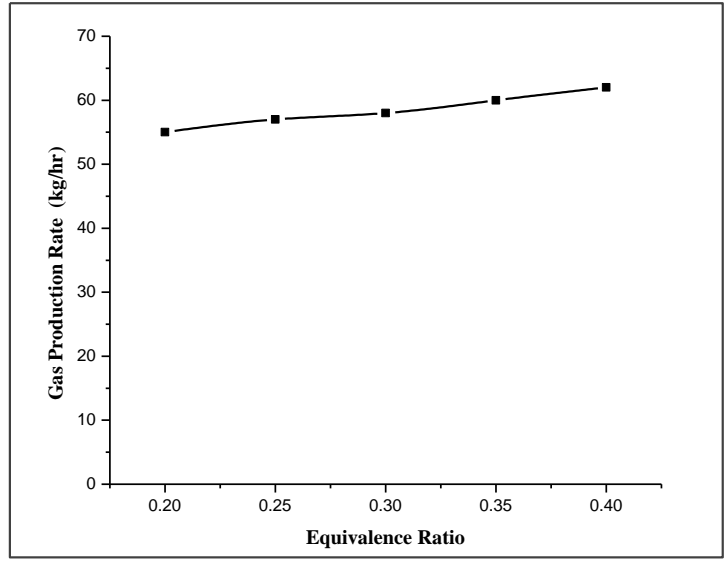

Figure 4 Equivalence ratio vs Gas production rate

\subsection{Equivalence ratio vs Gas production rate}

The Equivalence ratio is considered by many authors as the main factor for determining the performance of downdraft gasifier. According to Read \& das, Equivalence ratio as an important effect in the gas production rate, the gas energy content, the fuel consumption rate, the power output and char and tar production rate, and is independent of the reactor dimensions. Lower equivalence ratio results in a relative slow pyrolysis conditions mainly favoring the obtainment of a gas with high tar content on the contrary, the higher equivalence ratio, causes faster pyrolysis conditions favoring char production and gases with higher temperature in flaming zone. Never the less, there is also a considerable negative the effects, decline of the reduced time resulting in the unfavorable condition for the tar cracking when the gas steam passes through the combustion and gasification zone.This behavior is like the minor biomass consumption rate then the consequently to the minor producer gas generated.from thr graph figure. 4 it observed that

\subsection{Equivalence Ratio vs Gas Efficiency}

Equivalence ratio was calculated based on a function of a material factor which represents the amount of air needed to obtain combustion of $1 \mathrm{~kg}$ of dry biomass. Which was estimated based on stoichiometric calculations. It can be computed automatically from the elemental composition of the biomass. And the equivalence ratio was plotted against the efficiency of the gasifier. The graph from figure 5 it clearly shows the efficiency is decreasing from $60 \%$ to $45 \%$ while increasing of equivalence ratio from 0.2 to 0.4 .

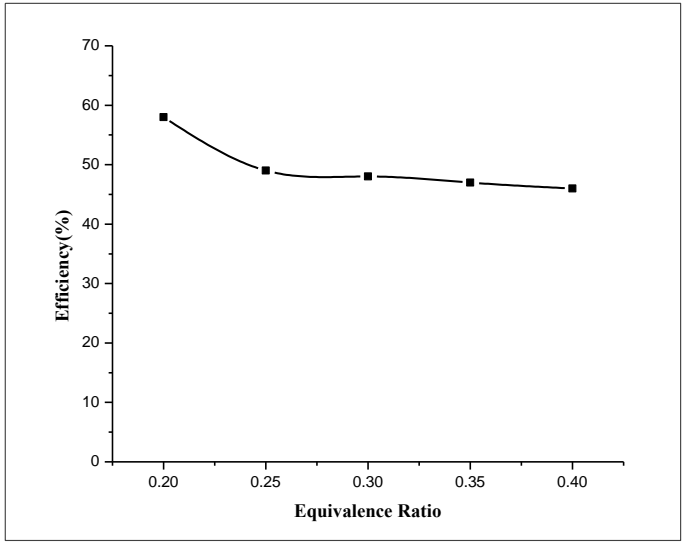

Figure 5. Equivalence ratio vs Efficiency

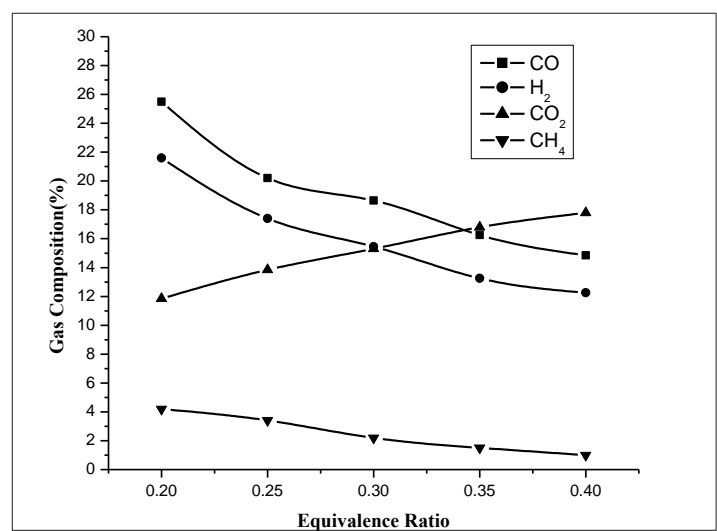

Figure 6. Equivalence ratio vs Gas composition

\subsection{Equivalence Ratio vs Gas composition}

From the graph figure 6 . it shows that the gas composition of the output gas from the gasifier. The above graph is plotted between equivalence ratio and gas composition. The graph clearly shows the composition of gases such as $\mathrm{Co}_{2} \mathrm{H}_{2}, \mathrm{CO}_{2}$, $\mathrm{CH}_{4}$ and they having the values of (in \%) 25.5, 21.6, 11.85, 4.1 respectively.

\section{CONCLUSION.}

The results from a detailed experimental analysis conducted on the $10 \mathrm{~kW}_{\mathrm{e}}$ Downdraft double throated Prosopis Juliflora wood gasifier with different equivalence ratio suggests that the optimum equivalence ratio for given biofuel and working 
conditions. it can be concluded from the results the equivalence ratio plays major role in the downdraft gasification. From the analysis we found that the optimum equivalence ratio and calorific value is 0.3 and $1042 \mathrm{kcal} / \mathrm{nm}^{3}$. The specific gasification rate,gas production rate, gas efficiency achieved by Prosopis Juliflora wood gas mode operation is $3 \mathrm{Nm}^{3} / \mathrm{Kg}, 55 \mathrm{~kg} / \mathrm{hr}, 55 \%$ respectively for given optimum equivalence ratio.

\subsection{REFERENCES}

1. Hall DO, Rosillo-Calle F, De Groot P., Biomass energy lessons from case studies in developing countries'. Energy Policy, Vol. 62-73.1992.

2. Siva Kumar.S., Pitchandi.K., and Natarajan .E. Modeling and simulation of down draftwood gasifier, Journal of Applied Sciences 8 (2): 271-279, 2008.

3. Tapas Kumar Patra, Pratik N. Sheth ,Biomass gasification models for downdraft gasifier: A state-of-the-art review, Renewable and Sustainable Energy Reviews, Volume 50, October, 583-593, 2015.

4. Felipe Centeno, Khamid Mahkamov, Electo E. Silva Lora, Rubenildo V. Andrade.,Theoretical and experimental investigations of a downdraft biomass gasifier-spark ignition engine power system Renewable Energy, January, Volume 37, Issue 1, 97-108, 2012.

5. Giltrap DL, Mckibbin R, Barnes GRG. A steady state model of gas-char reactions in a downdraft biomass gasifier. Solar Energy;74:85-91, 2003.

6. Jayah TH, Lu Aye, Fuller RJ, Stewart DF. Computer simulation of a downdraft wood gasifier for tea drying. Biomass and Bioenergy;25:459-69. 2003.

7. Gao N, Li A. Modeling and simulation of combined pyrolysis and reduction zone for a downdraft biomass gasifier. Energy Conversion and Management;49:34,83-90. 2008.

8. Sharma AK. Equilibrium modeling of global reduction reactions for a downdraft (biomass) gasifier. Energy Conversion and Management;49:8,32-42, 2008.

9. Ratnadhariya JK, Channiwala SA. Three zone equilibrium and kinetic free modeling of biomass gasifier e a novel approach. Renewable Energy 2009;34: 1050-8

10. Reed TB, Das A. Handbook of biomass downdraft gasifier engine system. Golden, CO: SERI,1988.

\section{Author' biography with Photo}

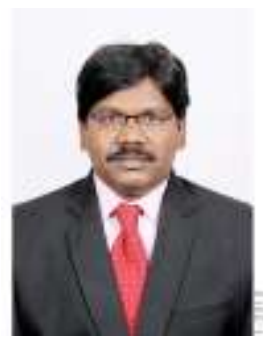

S.Sivakumar Completed his U.G in B.E., Mechanical Engineering and M.E., Engineering Design from Government college of Technology under Bharathiyar University. Prior to joining KCT,worked in the industry for 5 years and 12 years in teaching (worked as Teaching Research Associate (TRA) in college of Engineering Guindy,Anna university Chennai-25).he has research and engineering experience in various companies such as PRICOL, TVS,HEXDOF.he has worked on and managed number of FEA, CFD related design analysis projects for automotive, energy and pump industry. So for published 10 research articles of specialization area related to thermal equipment design in well reputed international journals with good impact factor, also presented 15 international conference and 5 national conference.

S. Ragunathan is working as a Principal and Professor at AVS Engineering College, Salem, India. His research interests include advanced manufacturing technology, CAD/CAM/robotics, non-traditiona optimization techniques, and fuzzy multiple attribute decision-making. He has vast experience of 20 years in teaching and research more than 50 research papers in international journals and conference proceedings. He is on the editorial board of many international journals 